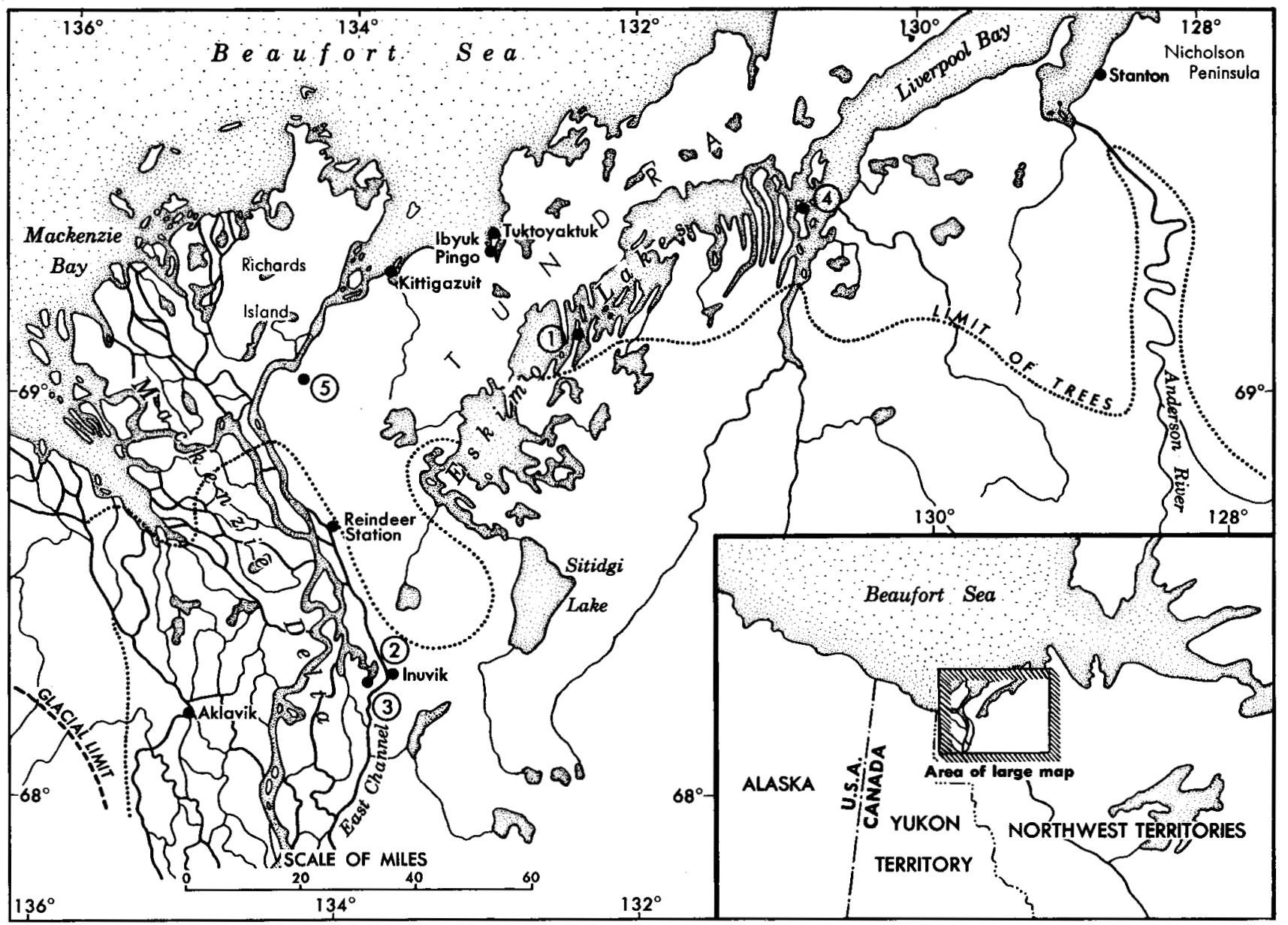

Fig. 1. Location Map. (1) Eskimo Lakes peat exposure. (2) Twin Lakes peat exposure. (3) Drill hole southwest of Inuvik. (4) Pingo with radiocarbon-dated driftwood. (5) Pingorssar ajuk pingo. Glacial limit after Bostock (1948). Limit of trees after Mackay (1963). 


\title{
POLLEN DIAGRAMS IN THE MACKENZIE DELTA AREA, N.W.T.
}

\author{
J. R. Mackay* and J. Terasmae $\dagger$
}

The purpose of this paper is to relate the palynological evidence obtained from a study of peat deposits, coupled with geological and other data, to the postglacial history of the Mackenzie Delta area. The two pollen diagrams published in this report, each with radiocarbon control, are the first for postglacial deposits in the Canadian Arctic, although palynological studies have been made at numerous other sites in the Arctic Archipelago and on the mainland (Terasmae 1961). In addition to the two pollen diagrams presented, palynological studies were also made of samples of alluvial sediments from a drill hole near Inuvik, N.W.T. Previous attempts to investigate the history of the vegetation were made by Simmons (1913) and Porsild (1938, 1955).

The geomorphological material has been based on field studies by J. R. Mackay, who also collected the samples of peat. The palynological analyses and their interpretation have been contributed by $\mathrm{J}$. Terasmae.

\section{Descriptions of exposures}

In the following descriptions of exposures the reader is reminded that the Mackenzie Delta has been accumulating at the mouth of a river valley slowly being drowned by the rising postglacial sea-level.

\section{Eskimo Lakes peat exposure}

The location of the peat exposure is along the western side of a peninsula in the Eskimo Lakes (Fig. 1, site 1). These lakes occupy parts of the former basin of a large postglacial lake, which was lowered when erosion breached the arcuate ridge, or ridges damming the lake. Peat accumulated at the drained lake bottom and was later dissected by subsequent erosion. The peat rests directly on sand with intermixed organic detritus, which is typical of local lacustrine bottom deposits (Fig. 2). The base of the peat bed is $3 \mathrm{ft}$. above the present lake level. As the tidal Eskimo Lakes are connected through a half-mile-wide channel to the sea, the bottom of the peat bed is thus within several feet of sea-level. The exposed face of the deposit is $7.5 \mathrm{ft}$. high, but its precise thickness is difficult to determine,

* Department of Geography, The University of British Columbia.

$\dagger$ Geological Survey of Canada, Department of Mines and Technical Surveys. 
because slumping unavoidably accompanies thawing of the frozen peat as the cutbank recedes, the top draping downward like a curtain. In addition, the frozen peat has a very high ice content, consequently the presence of ice must be considered when relating peat thickness to rate of growth. However, every effort was made to clean off the face of the exposure in order to obtain fresh undisturbed samples at 6-inch intervals. Wood from the bottom of the peat has been dated at 7,400 \pm 200 years (GSC-16).

A prominent wave-cut bluff, marking an early postglacial water-level 20 to $25 \mathrm{ft}$. above present sea-level, extends north from Sitidgi Lake along the creek joining it with the Eskimo Lakes, to a point east of the peat exposure under discussion (Mackay 1963, pp. 36-8). The bluff crosses the peninsula containing the peat exposure to form its southern boundary. The large postglacial lake, which was coextensive with the present Eskimo Lakes, was probably lowered by breaching of one or more of the arcuate ridges at the northeastern end of the lakes. The event occurred before 7,400 B.P. as shown by the radiocarbon date for the base of the peat. Subsequent to drainage peat commenced accumulating in a depression below the old shoreline. The peat deposit is now broken up into bun-shaped hummocks, 10 to $20 \mathrm{ft}$. in diameter, typical of the high-centred stage of tundra polygons. The hummocks are thickly covered with dwarf birch and lichens. It is therefore likely that the peat growth has been associated with the gradual transition from low-centred to high-centred polygons. The silt intermixed with the peat may have been blown in by wind from nearby mud boils and sandy beaches. The exposure of the peat has resulted from bank recession on the western side of the peninsula.

The vegetation in the surrounding area is tundra with scattered willow, alder, and dwarf birch. The limit of individual spruce is about 10 miles to the south (Fig. 1).

\section{Twin Lakes peat exposure}

The Twin Lakes lie between the town of Inuvik and the East Channel of the Mackenzie River, to which the lakes are joined by a short channel (Fig. 1, site 2). The peat at the Twin Lakes has probably accumulated also in a depression formed by the change from low-centred to high-centred polygons. The peat deposit has been exposed by undercutting and slumping along the eastern bank of the Twin Lakes. Although the base of the peat was clearly defined when examined, the stratigraphic succession immediately below the exposure was obscured by slumping, but it may be of alluvium with washed glacio-fluvial gravels or till. A radiocarbon date for the bottom of the peat gives an age of $8,200 \pm 300$ years (GSC-25).

\section{Mackenzie Delta occurrence}

In April 1961 a drilling program was carried out by the Division of Building Research, National Research Council, Ottawa, to determine the distribution of permafrost under a lake (Fig. 1, site 3) in the Mackenzie Delta at a site about $5 \mathrm{mi}$. southwest of Inuvik (Johnston and Brown 1961). 
Undisturbed cores indicated the following sediment profile: 0 to $100 \mathrm{ft}$., fine to medium sand throughout; 100 to $180 \mathrm{ft}$., fine to medium sand with thin layers of organic material in the upper $40 \mathrm{ft}$.; 180 to $240 \mathrm{ft}$., very dense clayey sediment free from stones except for the bottom few feet. A radiocarbon age of 6,900 \pm 110 years (GSC-54) was obtained for a specimen 125 ft. below the surface from bore hole No. 3. As the ground surface is 15 to $20 \mathrm{ft}$. above sea-level, the specimen came from a depth of about 105 to 110 ft. below present sea-level. The basal stony material may be till or reworked till. The uppermost 180-foot section is composed of alluvium deposited in an estuary of unknown depth, but at no time did the sea surface reach as high as the top of the Twin Lakes peat exposure, which reflects 8,200 years of sub-aerial accumulation.

\section{Geomorphological interpretation of exposures}

All the areas represented by the exposures have been glaciated, but direct evidence for late Wisconsin glaciation is based solely on a section at Ibyuk pingo, near Tuktoyaktuk. Müller (1962) has described a till underlain by driftwood 28,000 22,000 years (Be-49) old. If the updomed layers of the pingo were to be returned to their original position, the driftwood would lie 20 to $25 \mathrm{ft}$. below present sea-level. If the driftwood reliably indicates sea-level at the time of deposition, then rather close limits are established for an ice advance to the area of Tuktoyaktuk. Müller (1962, p. 285) estimates the glacierization that produced the till as occurring between 25,000 and 15,000 years ago, hence in late Wisconsin time. At the pingo Müller (1962, p. 283) has described a section with driftwood $12,000 \pm 300$ years (S-69) old above the till. The environment of the wood suggests deposition in shoal water. Müller believes the age of the driftwood to be nearly the same as that of the enclosing sediments. If the updomed layers of the pingo were returned to their original position, the driftwood would lie about $15 \mathrm{ft}$. below present sea-level.

A situation similar to that at the Ibyuk pingo occurs at site 4 of Fig. 1 in the Eskimo Lakes, where a driftwood fragment $15 \mathrm{ft}$. below the top of a pingo has been dated at 10,800 \pm 300 years (I-483; Geographical Branch JRM-60-W2). If the pingo material were returned to its original position it would be 15 to $20 \mathrm{ft}$. below present sea-level.

The dating of sediments by means of included driftwood may be risky. At present driftwood is carried down the Mackenzie River - the principal source is the Liard River, but some also comes from undercutting of forested banks within the Mackenzie Delta - and is then carried east and west of the Delta by currents. As the tidal range is only 1 to $2 \mathrm{ft}$. the maximum upper limit of modern driftwood is rarely more than about $8 \mathrm{ft}$. above sea-level, which marks the upper limit of storm wave transport. The driftwood is swept on to the low alluvial islands and into shallow lakes and marshes where it is buried. However, there is no assurance that the Mackenzie River or other northward flowing rivers, which now transport driftwood to the coast, crossed forested areas 11,000 to 12,000 years ago. This 
poses the interesting question as to whether coastal forests could have become established so soon after deglaciation. Although redeposition is possible, this still leaves unsolved the ultimate source of the 11,000-to12,000-year-old driftwood. Irrespective of the precise origin of the driftwood, the evidence suggests the area was icefree 12,000 years ago.

In the interval of some 4,000 years beginning about 12,000 to 11,000 years ago, when the postglacial driftwood in the pingos is inferred to have been deposited, and 8,000 to 7,000 years ago, when peat at the Twin Lakes and the Eskimo Lakes began accumulating, local sea-level was in relation to the land the same as at present, or more likely lower. At the Twin Lakes as well as at the Eskimo Lakes the peat exposures show every evidence of subaerial accumulation and thus provide two excellent maximum marine limits for the past 7,000 to 8,000 years. There is good evidence, especially from drowned valleys 50 to $150 \mathrm{ft}$. deep, to indicate that sea-level was considerably lower during at least the early period of peat accumulation; for example, the drowned valley used as a deep water harbour at Tuktoyaktuk, near Ibyuk pingo, is $\mathbf{5 0}$ feet deep.

\section{Palynological studies}

A comparison of the two pollen diagrams (Figs. 2 and 3) for the Eskimo Lakes and Twin Lakes peat exposures shows rather good correlation. The basal levels in the Eskimo Lakes diagram correlate with the 7- and 8-foot depths in the Twin Lakes diagram. These levels are characterized by relatively high percentages of birch (Betula), willow (Salix) and sedges (Cyperaceae), followed upward by higher percentages of heathers (Ericaceae) and later by alder (Alnus). This correlation lends support to the interpretation that these changes in pollen abundance are not merely local phenomena but more likely regional ones caused by environmental changes. It can be inferred from both this correlation and the radiocarbon date of 7,400 B.P. that some $7.5 \mathrm{ft}$. of silty peat accumulated in about 7,500 years. However, there is no proof that the rate of accumulation was uniform. Inasmuch as the ice content of peat is extremely high (Pihlainen 1962) and the thickness of the active layer undoubtedly fluctuated during the period of accumulation it is by no means certain that the growth of peat proceeded at a uniform rate.

The pollen from the drill core 5 miles southwest of Inuvik is poorly preserved in the sediments studied and some redeposition is shown by the presence of pre-Pleistocene (Mesozoic and Palaeozoic) spores at several levels. The results obtained indicate that many sources of error are encountered in palynological studies of such alluvial sediments. The radiocarbon date of 6,900 years for the sample from $125 \mathrm{ft}$. below the surface is compatible with other evidence for contemporaneous deposition.

It is necessary to point out that the term "tree pollen" has been used loosely in this report for calculation of percentages of different pollen types. All percentages shown in the diagrams Figs. 2 and 3 are based on the total 
of "tree pollen", including spruce, pine, fir, birch, alder, and willow; where the birch, alder, and willow probably should be called shrubs rather than trees. This has been done chiefly for convenience of comparison with pollen diagrams from other regions farther south. Furthermore, both diagrams are truncated at the base and hence do not show the late-glacial pollen assemblages. However, it is interesting to note that already 8,200 years ago spruce (Picea) grew in the area as indicated by the high percentage of it at the dated level. The occurrence of Shepherdia and Artemisia pollen in the basal assemblages probably indicates the presence of newly emerged sites of alluvial or lacustrine soils. The pollen diagrams, supported by radiocarbon dates, indicate that the time interval from about 8,200 to 7,500 B.P. was characterized not only by the presence of spruce and birch but also by a vegetation in which Salix, Cyperaceae, Shepherdia, Artemisia, and Gramineae were widespread. Ericaceae and Alnus were apparently of little importance. However, beginning some 7,000 years ago Ericaceae gained in importance and greater soil acidity with development of bogs is further implied by the presence of peat moss (Sphagnum) spores and Myrica pollen. This may have been the transition from low-centred to high-centred polygons. A marked increase in the percentage of alder pollen begins some 2,000 to 3,000 years ago and rises to a maximum in more recent times.

\section{Postglacial climatic changes}

The sequence of postglacial climatic changes, although apparent from the studies made cannot yet be satisfactorily interpreted from the available evidence. Radiocarbon dates for driftwood in the Ibyuk pingo and for that at site 4, Fig. 1 suggest that the area was icefree 12,000 to 11,000 years ago. No data are available between this period and 8,200 B.P., when the Twin Lakes peat began to accumulate. However, the area was probably then forested to the same extent as at present. It is also quite possible that postglacial reforestation began much earlier south of the area studied and to the west of it. Evidence for a warmer postglacial climate than the present is widespread. Porsild (1938) has found several plant species living now in the Eskimo Lakes basin, which occur generally only much farther south. He considered them relics of a former, more favourable period. Support for Porsild's evidence was found south of this area by Terasmae, who discovered that Ceratophyllum demersum L. extended north of its present range (Thieret 1962) about 5,400 (L-428) years ago (Terasmae and Craig 1958). Fossils of this species were found by Craig in lacustrine beds heaved up in a pingo in the Thelon River valley (Craig 1959). On Richards Island at the northeastern side of the Mackenzie Delta fossil spruce stumps occur in situ under several feet of peat (Porsild 1938, p. 57). Near Kittigazuit spruce stumps over 8 inches in diameter are buried below recent peat and windblown sand. In the Eskimo Lakes-Nicholson Peninsula-Stanton area old spruce logs are found 20 to 30 miles north of the present limit of spruce. Some 


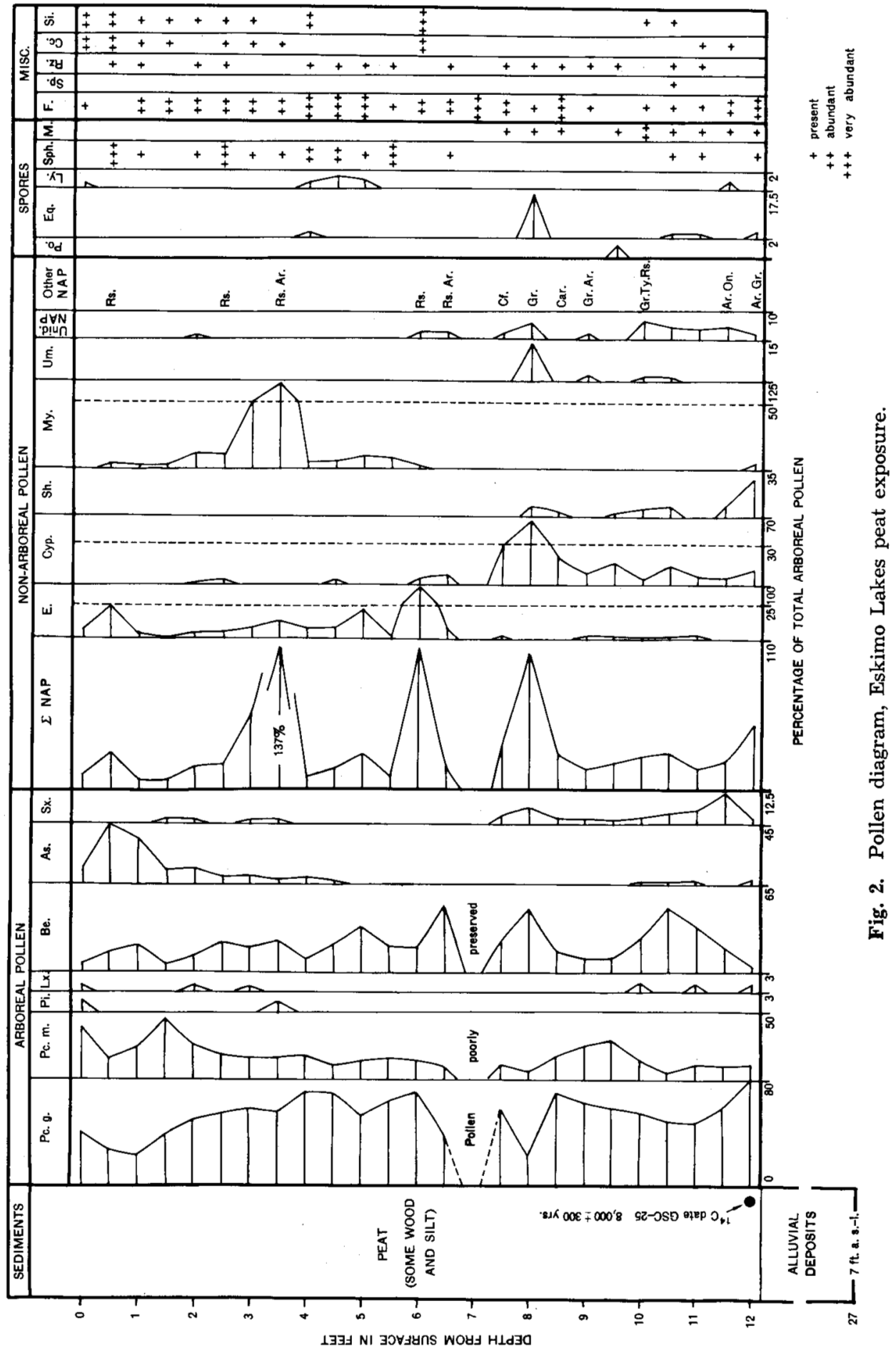



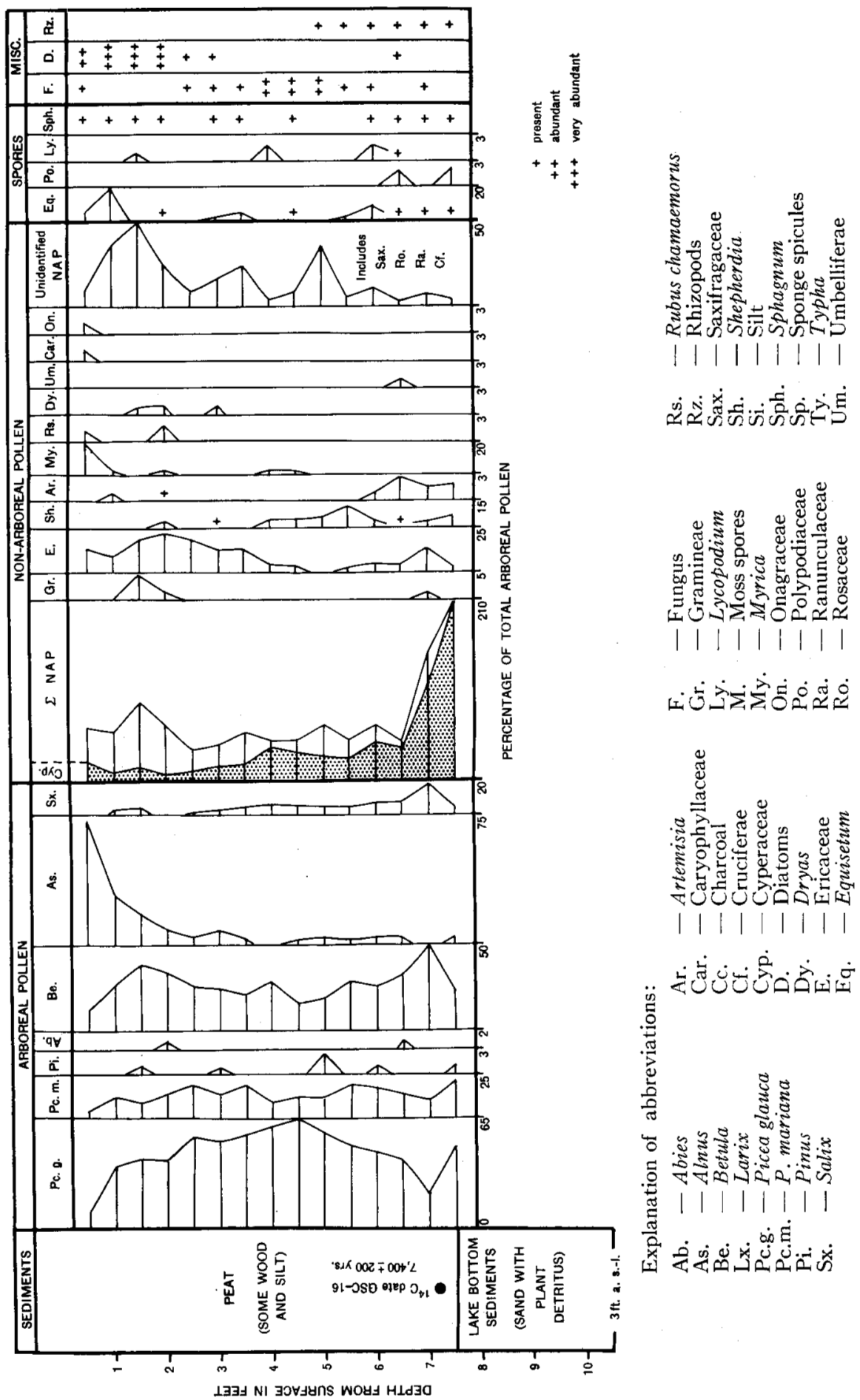

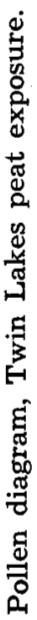

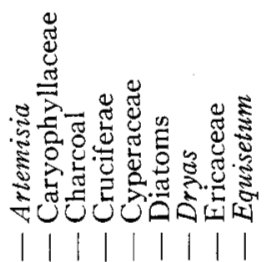

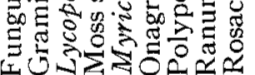

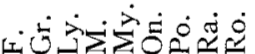
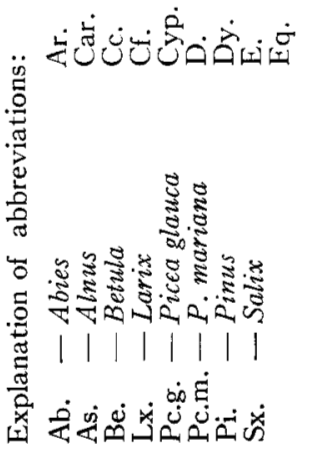
of the logs are buried in peat beds, others lie on the surface of the ground. However, living single prostrate spruce may still be found in a few areas as far as 30 miles beyond the "limit" of spruce.

Porsild (1938, pp. 52, 57) found fossil Potamogeton epihydrus var. nutallii in the sediments exposed in the Pingorssarajuk pingo (Fig. 1, site 5). Iversen examined pollen in samples collected from this pingo (Porsild 1938, p. 52) and a correlation of pollen assemblages found by him with those in the diagrams presented here indicates that the sediment examined by Iversen is of late postglacial age and that the pingo was probably formed within the last 2,000 to 1,000 years, or later.

It would be expected on the basis of the above evidence that the postglacial hypsithermal interval (with a more favourable climate than the present) should be shown in the pollen diagrams of this report. It should fall in the upper half of the Twin Lakes pollen diagram. Livingstone (1955, p. 598) concluded from his palynological studies made in the Brooks Range of Alaska south of Barrow that "conditions in tundra regions are not favourable for the registration of even such major climatic phenomena as the postglacial thermal maximum". However, his diagrams show an increase in the abundance of alder pollen in late postglacial time comparable to that found in the Mackenzie Delta area, preceded by higher percentages for birch and still earlier for sedges. Pollen of spruce and Ericaceae drop to very small percentages in his northern area, whereas the greater percentages of Cyperaceae (in the lower part of Livingstone's diagrams) are supported by those of Artemisia, grasses and willows, thus adding to the similarity with diagrams from the Mackenzie Delta.

The late postglacial increase in the abundance of alder pollen is an interesting feature. Livingstone believed, assuming a deteriorating climate, that in his area this increase - there is no alder growing in Livingstone's study area now, nor did he find any fossils of it - could be explained by transport over moderate distances by wind of alder (Alnus viridis) pollen, resulting in an apparent increase at the expense of the decreasing local pollen production of plant species at the site. Heusser (1960) in his palynological studies in Pacific coastal Alaska found that alder (Alnus crispa ssp. sinuata) pollen percentages decreased during late postglacial time, and he considered this to indicate a cooling of climate. Highest percentages of alder were encountered by Heusser in the hypsithermal zone. He considered Myrica to be a cool-climate indicator and he found that Ericaceae were most abundant in the late hypsithermal zone. About $100 \mathrm{mi}$. west of the Mackenzie Delta and slightly over $10 \mathrm{mi}$. south of the coast pollen from a buried organic layer indicates a warmer climate than the present, judging from comparisons with pollen from higher horizons at the site as well as from pollen spectra of lake deposits of northern Alaska (Mackay, Mathews, and MacNeish 1961, p. 31; pollen identifications by J. Terasmae). Other evidence suggests a minimum age for the warmer climate of several thousand years.

Indirect evidence for climatic change comes from a study of the ages of the pingos of the Mackenzie Delta area. Most of the 1,400 pingos have a 
cover of vegetation with an underlying thin peat layer, tundra polygons with ice wedges many feet in width, and a thicker peat deposit is feathering out against the sides. From the best available evidence for the rate of accumulation of peat and the growth of ice wedges the majority of pingos are probably well over a thousand years old (Mackay 1962, pp. 58-60). Since the closed-system pingos, characteristic of the area, develop through the formation of an impervious permafrost seal over an unfrozen basin, the "triggering" mechanism can be either a geomorphic or climatic change. For the Mackenzie Delta pingos a cooling trend for the past few thousand years accompanied by diminishing precipitation would best account for pingo formation.

The following, decidedly tentative sequence of climatic events is proposed for the Mackenzie Delta area. Deglaciation occurred about 12,000 years ago. Palynological studies indicate a rather cool-dry climate (compared with the present) from 8,500 to 7,500 years ago. This episode was followed by a warmer one with possibly less available moisture and with more rapid decay of peat locally (pollen poorly preserved, peat accumulation slow). A later increase in available moisture has been assumed to be indicated by a maximum of Ericaceae. The maximum of Myrica pollen suggests a probable cooling of the climate with a later increase in moisture as shown by an increase of alder and Ericaceae. The abundance of Sphagnum spores in the upper part of the Twin Lakes diagram lends support to the assumption of increased available moisture in late postglacial time. A cooling was associated with the formation of many pingos in the past several thousand years.

\section{Acknowledgements}

The samples of alluvial sediments near Inuvik (Fig. 1, site 3) were collected by G. H. Johnston and R. J. E. Brown (National Research Council, Ottawa) and their co-operation is gratefully acknowledged. The writers would like to thank Drs. W. H. Mathews and J. G. Fyles for helpful comments. The study of J. R. Mackay was carried out for the Geographical Branch, Ottawa and that of J. Terasmae for the Geological Survey of Canada, Ottawa.

\section{References}

Bostock, H. S. 1948. Physiography of the Canadian Cordillera, with special reference to the area north of the fifty-fifth parallel. Ottawa: Geol. Surv. Mem. 247, 106 pages.

Craig, B. G. 1959. Pingo in the Thelon Valley, Northwest Territories; radiocarbon age and historical significance of the contained organic material. Bull. Geol. Soc. Am. 70:509-10.

Craig, B. G., and J. G. Fyles. 1960. Pleistocene geology of arctic Canada. Ottawa: Geol. Surv. Pap. 60-10, 21 pages.

Heusser, C. J. 1960. Late-Pleistocene environments of North Pacific North America. Am. Geog. Soc. Spec. Pub. 35, 308 pages. 
Johnston, G. H., and R. J. E. Brown. 1961. Effect of a lake on distribution of permafrost in the Mackenzie Delta. Nature 192:251-2.

Livingstone, D. A. 1955. Some pollen profiles from arctic Alaska. Ecology 36:587-600. Mackay, J. R. 1962. Pingos of the Pleistocene Mackenzie Delta area. Ottawa: Geog. Bull. 18 , pp. 21-63.

202 pages.

1963. The Mackenzie Delta area, N.W.T. Ottawa: Geogr. Br. Mem. 8,

Mackay, J. R., W. H. Mathews, and R. S. MacNeish. 1961. Geology of the Engigstciak archaeological site, Yukon Territory. Arctic 14:25-52.

Müller, F. 1962. Analysis of some stratigraphic observations and radiocarbon dates from two pingos in the Mackenzie Delta area, N.W.T. Arctic 15:278-88.

Pihlainen, J. A. 1962 . Inuvik, N.W.T., Engineering site information. Ottawa: Natl. Res. Coun. Div. Bldg. Res. Tech. Pap. 135, 18 pages.

Porsild, A. E. 1938. Earth mounds in unglaciated arctic northwestern America. Geog. Rev. 28:46-58.

-1955. The vascular plants of the western Canadian Arctic Archipelago. Natl. Mus. Can. Bull. 135, 226 pages.

Simmons, H. G. 1913. A survey of the phytogeography of the arctic American Archipelago. Kungl Fysiogr. Sällsk. Handl. N.F. 24:19.

Terasmae, J. 1961. Notes on late-Quaternary climatic changes in Canada. Ann. New York Acad. Sci. 95:658-75.

Terasmae, J., and B. G. Craig. 1958. Discovery of fossil Ceratophyllum demersum L. in Northwest Territories, Canada. Can. J. Bot. 36:567-9.

Thieret, J. W. 1962. New plant records from District of Mackenzie, Northwest Territories. Can. Field-Nat. 76:206-8. 